\title{
PLANINIŲ ORTOPEDINIŲ TRAUMATOLOGINIŲ PASLAUGŲ PRIEINAMUMO POKYČIAI COVID-19 PANDEMIJOS METU
}

\author{
Agnè Česnauskaitė ${ }^{1}$, Andrius Montrimas', Vytautas Venclovas² \\ ${ }^{1}$ Lietuvos sveikatos mokslu universitetas, \\ ${ }^{2}$ Lietuvos sveikatos mokslu universiteto Kauno ligonine, Chirurgijos klinika
}

\author{
Raktažodžiai: Covid-19 pandemija, planinès ortopedinès \\ traumatologinès paslaugos.
}

\section{Santrauka}

Ivadas. 2020 kovo 11 dieną Pasaulio sveikatos organizacija paskelbė Covid-19 pandemiją, kuri užklupo daugelị sveikatos sistemų nepasiruošusias, sveikatos įstaigoms teko perskirstyti turimus išteklius Covid-19 pacientams. Tyrimo tikslas - įvertinti planinių ortopedinių traumatologinių paslaugų prieinamumo pokyčius Covid-19 pandemijos metu.

Metodai. Retrospektyvus tyrimas, kurio populiacija buvo vieno ortopedo traumatologo planingai konsultuoti ir operuoti pacientai LSMU Kauno ligoninès Chirurgijos klinikoje (Hipodromo g. 13) nuo 2019 m. liepos 16 d. iki 2020 lapkričio 9 dienos. Tiriamieji buvo suskirstyti i 3 grupes, kurios buvo palygintos tarpusavyje: G1 - operacijos iki pirmojo karantino Lietuvoje (2020 m. kovo 16 d.) (143 pacientai); G2 - pacientai, kurių pirmoji planinè ortopedo traumatologo konsultacija buvo iki 2020 kovo 16 d., o operacija po šios datos (44 pacientai); G3 - tiriamieji, kurių pirmoji planinė ortopedo traumatologo konsultacija ir operacija buvo po 2020 kovo 16 d. (61 pacientas). Statistinè analizè atlikta naudojant IBM SPSS statistinès įrangos paketo 26 versiją.

Rezultatai. Nuo 2019 m. liepos 16 d. iki 2020 m. kovo 15 d. ortopedas traumatologas atliko 1547 planines konsultacijas ir 225 planines operacijas, o nuo $2020 \mathrm{~m}$. kovo 16 d. iki 2020 m. lapkričio 9 d. 812 planinių konsultacijų ir 127 planines operacijas. Vidutinis operacijų $(3,6 \pm 1,4)$ ir konsultacijų $(17,6 \pm 1,6)$ skaičius per darbo dieną operacinejje ir poliklinikoje prieš pirmajị karantiną Lietuvoje buvo statistiškai reikšmingai didesnis, nei po karantino: atitinkamai 3,0 $\pm 1,0(\mathrm{p}=0,035)$ ir $13,5 \pm 2,0(\mathrm{p}<0,001)$. G2 grupès pacientų laukimo laiko nuo pirmos konsultacijos iki antros $\left(\mathrm{p}=0,001^{\mathrm{ab}}, \mathrm{p}<0,001^{\mathrm{bc}}\right)$, nuo traumos iki operacijos $\left(p=0,004^{\mathrm{ab}}, \mathrm{p}<0,001^{\mathrm{bc}}\right)$ ir nuo pirmos konsultaci- jos iki operacijos ( $\left.\mathrm{p}<0,001^{\mathrm{ab}}, \mathrm{p}<0,001^{\mathrm{bc}}\right)$ medianos buvo statistiškai reikšmingai didesnès, lyginant su G1 ir G3 grupèmis. G1 grupès laukimo laiko mediana nuo traumos iki operacijos $\left(p=0,036^{\text {ac }}\right)$ ir nuo pirmos konsultacijos iki operacijos $\left(\mathrm{p}=0,006^{\mathrm{ac}}\right)$ buvo statistiškai reikšmingai didesnè, negu G3 grupès.

Išvados . Ortopedo traumatologo planinių konsultacijų ir operacijų skaičius nuo pirmojo karantino Lietuvoje paskelbimo pradžios (2020 m. kovo 16 d.) iki antrojo karantino Lietuvoje pradžios (2020 m. lapkričio 9 d.) buvo beveik dvigubai mažesnis, lyginant su tokiu pačiu laikotarpiu prieš karantiną. Atnaujinus planines ortopedines traumatologines paslaugas po pirmojo karantino Lietuvoje, pacientų srautas buvo mažesnis negu iki karantino, todèl sutrumpejo laukimo laikas nuo traumos ir pirmos planinès ortopedo traumatologo konsultacijos iki operacijos. Pacientai, kuriems pirmoji planinè ortopedo traumatologo konsultacija buvo atlikta prieš karantiną, o operacija po jo, ilgiau laukè nuo pirmos konsultacijos iki antros, nuo traumos ir pirmos konsultacijos iki operacijos, lyginant su tais, kurie buvo operuoti iki karantino ar gavo pirmają konsultaciją ir buvo operuoti po karantino.

\section{Ivadas}

Covid-19 yra užkrečiamoji liga, kurią sukelia SARSCov-2 virusas [1-3]. Pirmieji šios ligos atvejai buvo užfiksuoti Uhane, Kinijoje 2019 metų gruodi [1-3]. Liga dažniausiai pasireiškia šiais simptomais: karščiavimu, kosuliu, nuovargiu, dusuliu, uoslès ir skonio praradimu, kartais gastrointestinaliniais simptomais, tokiais kaip viduriavimas, vėmimas [1,3-5]. Apie 80 proc. pacientų serga besimptome ar lengva ligos forma, tačiau daliai pacientų išsivysto sunkios komplikacijos, tokios kaip pneumonija, sepsis, kvėpavimo nepakankamumas ar ūminis respiracinis distreso sindromas [3]. Dèl greito ligos plitimo ir galimų sunkių komplikacijų, 2020 m. kovo 11 dieną Pasaulio sveikatos organizacija paskelbè Covid-19 pandemiją [2,3]. Co- 
vid-19 pandemija užklupo daugeli sveikatos sistemų nepasiruošusias, todèl teko imtis griežtų priemonių ir perskirstyti turimus išteklius Covid-19 pacientams, todèl nukentejo kitų infekcinių ir neinfekcinių ligų gydymas [6-11].

Tyrimo tikslas - ivvertinti planiniu ortopedinių traumatologiniu paslaugu prieinamumo pokyčius Covid-19 pandemijos metu.

\section{Tyrimo medžiaga ir metodai}

Tyrimas retrospektyvus, atliktas Lietuvos sveikatos mokslų universiteto (LSMU) Kauno ligoninès Chirurgijos klinikoje (Hipodromo g. 13), kurioje pirmojo karantino Lietuvoje metu nuo $2020 \mathrm{~m}$. kovo 16 d. iki $2020 \mathrm{~m}$. birželio $15 \mathrm{~d}$. buvo sustabdytos planinès ortopedinès traumatologinès paslaugos. Tyrimas atliktas gavus Kauno regioninio biomedicininių tyrimų etikos komiteto leidimą BE-2-25. Tyrimo populiacija buvo vieno gydytojo ortopedo traumatologo planingai konsultuoti ir operuoti pacientai LSMU Kauno ligoninès Chirurgijos klinikoje nuo 2019 m. liepos 16 d. iki $2020 \mathrm{~m}$. lapkričio 9 d. (antrojo karantino Lietuvoje paskelbimo). Šiuo laikotarpiu buvo atliktos 2359 konsultacijos ir 352 operacijos. Visos konsultacijos ir operacijos buvo suskirstytos i grupes: 1 grupè - konsultacijos ir operacijos nuo $2019 \mathrm{~m}$. liepos 16 d. iki pirmojo karantino Lietuvoje (2020 m. kovo 16 d.) paskelbimo; 2 grupe - konsultacijos ir operacijos po karantino, nuo $2020 \mathrm{~m}$. birželio 15 d. iki 2020 m. lapkričio 9 dienos. Suteiktų paslaugų duomenys naudoti lyginant absoliučius konsultacijų ir operacijų skaičius, darbo dienų poliklinikoje ir operacinèje procentinę dali nuo visų darbo dienų bei vidutini konsultacijų ir operacijų skaičių per darbo dieną. Iš 352 operacijų likusiems skaičiavimams naudoti 248 operacijų duomenys, kurių elektroninèje medicininèje informacijoje rasta arba paciento traumos, arba pirmos, arba antros planinès ortopedo traumatologo konsultacijos data. Šios 248 operacijos buvo suskirstytos i 3 grupes: G1 - operacijos iki pirmojo karantino Lietuvoje (2020 m. kovo 16 d.) (143 pacientai); G2 - pacientai, kurių pirmoji planinè ortopedo traumatologo konsultacija buvo iki 2020 kovo $16 \mathrm{~d}$., o operacija po šios datos (44 pacientai); G3 - tiriamieji, kurių pirmoji planinè ortopedo traumatologo konsultacija ir operacija buvo po 2020 kovo $16 \mathrm{~d}$. (61 pacientas).

Atliekant elektroninių medicininių duomenų analizę, buvo renkama informacija apie vieno ortopedo traumatologo planinių konsultacijų ir operacijų skaičių, datas,

1 lentelè. Vieno ortopedo traumatologo planinès paslaugos $2019 \mathrm{~m}$. liepos $16 \mathrm{~d}$. - $2020 \mathrm{~m}$. lapkričio $9 \mathrm{~d}$.

*vidurkis \pm standartinis nuokrypis.

\begin{tabular}{|c|c|c|c|}
\hline \multirow[b]{2}{*}{ Kintamieji } & \multicolumn{2}{|c|}{ Tyrimo grupės } & \multirow[b]{2}{*}{ p reikšmė } \\
\hline & $\begin{array}{c}\text { 1 grupé } \\
(201907 \\
16-202003 \\
15)^{\mathrm{a}} \\
\end{array}$ & $\begin{array}{c}\text { 2 grupé } \\
(202006 \\
15-202011 \\
09)^{\mathrm{b}} \\
\end{array}$ & \\
\hline Kalendorinių dienų skaičius & 245,0 & 148,0 & - \\
\hline Darbo dienų skaičius & 168,0 & 103,0 & - \\
\hline $\begin{array}{l}\text { Darbo dienų operacinèje skaičius } \\
\text { (proc. nuo darbo dienų) }\end{array}$ & $62,0(25,3 \%)$ & $42,0(28,4 \%)$ & $0,504^{\mathrm{ab}}$ \\
\hline Operacijų skaičius & 225,0 & 127,0 & - \\
\hline Operacijų skaičius per darbo dieną operacinèje* & $3,6 \pm 1,4$ & $3,0 \pm 1,0$ & $0,035^{\mathrm{ab}}$ \\
\hline $\begin{array}{l}\text { Darbo dienų konsultacinèje poliklinikoje skai- } \\
\text { čius (proc. nuo darbo dienų) }\end{array}$ & $88,0(52,4 \%)$ & $60,0(58,3 \%)$ & $0,346^{\mathrm{ab}}$ \\
\hline Konsultacijų skaičius & 1547,0 & 812,0 & - \\
\hline $\begin{array}{l}\text { Konsultacijų skaičius per darbo dieną konsulta- } \\
\text { cineje poliklinikoje* }\end{array}$ & $17,6 \pm 1,6$ & $13,5 \pm 2,0$ & $<0,001^{\mathrm{ab}}$ \\
\hline $\begin{array}{l}\text { Konsultacijų skaičius per darbo valandą konsul- } \\
\text { tacinejje poliklinikoje* }\end{array}$ & $4,4 \pm 0,4$ & $2,4 \pm 1,0$ & $<0,001^{\mathrm{ab}}$ \\
\hline
\end{tabular}

2 lentelè. Tiriamujų charakteristikos ir atliktos operacijos.

*mediana (Q1;Q3); $n$-operaciju skaičius; PKR - priekinis kryžminis raištis.

\begin{tabular}{|l|c|}
\hline Kintamasis & Visos operacijos (n=248) \\
\hline Amžius (metai)* & $57,0(49,0 ; 63,0)$ \\
\hline Lytis (vyras) & $96,0(38,7 \%)$ \\
\hline Operacijos trukmė (minutės)* & $30,0(25,0 ; 55,0)$ \\
\hline Ne pirma tos srities operacija & $13,0(5,2 \%)$ \\
\hline Kelio operacija nesant visiško PKR plyšimo & $82,0(33,1 \%)$ \\
\hline Kelio operacija esant visiškam PKR plyšimui & $7,0(2,8 \%)$ \\
\hline Peties operacija nesant visiško peties manžetės raumens plyšimo & $33,0(13,3 \%)$ \\
\hline $\begin{array}{l}\text { Peties operacija, esant visiškam peties manžetės raumens ply- } \\
\text { šimui }\end{array}$ & $41,0(16,5 \%)$ \\
\hline Riešo tunelinio sindromo operacija & $57,0(23,0 \%)$ \\
\hline Riešo ir alkūnės tunelinio sindromo operacija & $9,0(3,6 \%)$ \\
\hline Alkūnès tunelinio sindromo operacija & $5,0(2,0 \%)$ \\
\hline Gangliono operacija & $4,0(1,6 \%)$ \\
\hline Pėdos didžiojo piršto operacija & $9,0(3,6 \%)$ \\
\hline Spragsinčio piršto operacija & $1,0(0,4 \%)$ \\
\hline
\end{tabular}


pacientų amžių, lytị, traumos, planinių ortopedo traumatologo konsultacijų datas, operacijų indikacijas, ar tai buvo pirma tos srities operacija, kokia buvo operacijos trukmè. Jeigu nebuvo žinoma pirmos planinès ortopedo traumatologo konsultacijos data ir buvo žinoma tik apie vieną konsultaciją, i kurią pacientas atejo su atlikto magnetinio rezonanso tyrimo atsakymu, buvo daroma prielaida, jog tai antroji paciento konsultacija. İ operacijos trukmę nebuvo įskaičiuojamas pasiruošimo operacijai ir anestezijos laikas. Darbo dienų skaičius tam tikru laikotarpiu buvo nustatomas pasitelkiant internetinę darbo dienų skaičiuoklę.

Statistinè duomenų analizė atlikta naudojant IBM SPSS statistinès įrangos paketo 26 versiją, p reikšmé, mažesnè nei 0,05 , buvo laikoma statistiškai reikšminga. Shapiro-Wilk ir Kolmogorov-Smirnov testai buvo naudojami nustatyti, ar kiekybinių kintamujų skirstinys yra normalusis. Kiekybinių kintamujų, kurių skirstinys buvo normalusis, vidurkiai buvo lyginami naudojant vienfaktorinę dispersinę analizę, o tiems, kurių skirstinys nebuvo normalusis, buvo skaičiuojama mediana ir statistiškai reikšmingi skirtumai buvo nustatomi naudojant medianos testą. Kokybiniai kintamieji buvo lyginami naudojant požymių dažnių lenteles, o skirtumų statistinis

3 lentelè. Planinių ortopedinių traumatologinių paslaugų laukimo trukmè.

*mediana (Q1;Q3); $n$-operaciju skaičius; ${ }^{a c}$ - lyginamosios G1 ir G3 grupés; ${ }^{a b}$ - lyginamosios G1 ir G2 grupés; bc - lyginamosios G2 ir G3 grupès.

\begin{tabular}{|c|c|c|c|c|}
\hline \multirow[b]{2}{*}{ Kintamieji } & \multicolumn{3}{|c|}{ Tiriamųjų grupès } & \multirow[b]{2}{*}{$\underset{\text { reikšmè }}{\mathbf{p}}$} \\
\hline & $\begin{array}{c}\text { G1 - pirmoji } \\
\text { konsultacija ir } \\
\text { operacija iki } \\
20200316^{\mathrm{a}} \\
(\mathrm{n}=143)\end{array}$ & $\begin{array}{c}\text { G2 - pirmoji kon- } \\
\text { sultacija iki } 2020 \\
0316, \text { o operacija } \\
\text { po }^{\text {b }}(n=44)\end{array}$ & $\begin{array}{c}\text { G3 - pirmoji } \\
\text { konsultacija ir } \\
\text { operacija po } 2020 \\
0316^{c} \\
(\mathrm{n}=61)\end{array}$ & \\
\hline Amžius (metai)* & $58,0(49,0 ; 63,0)$ & $54,5(50,0 ; 62,8)$ & $58,0(46,0 ; 68,0)$ & $\begin{array}{l}0,715^{\mathrm{ac}} \\
0,104^{\mathrm{ab}} \\
0,182^{\mathrm{bc}}\end{array}$ \\
\hline Lytis (vyrai) & $51,0(35,7 \%)$ & $16,0(36,4 \%)$ & $29,0(47,5 \%)$ & $\begin{array}{l}0,112^{\mathrm{ac}} \\
0,933^{\mathrm{ab}} \\
0,253^{\mathrm{bc}}\end{array}$ \\
\hline $\begin{array}{l}\text { Ne pirma tos } \\
\text { srities operacija }\end{array}$ & $9,0(6,3 \%)$ & $3,0(6,8 \%)$ & $1,0(1,6 \%)$ & $\begin{array}{l}0,159^{\mathrm{ac}} \\
0,901^{\mathrm{ab}} \\
0,171^{\mathrm{bc}}\end{array}$ \\
\hline $\begin{array}{l}\text { Operacijos trukmè } \\
\text { (minutess)* }\end{array}$ & $30,0(20,0 ; 50,0)$ & $35,0(26,3 ; 58,8)$ & $30,0(20,0 ; 65,0)$ & $\begin{array}{l}0,690^{\mathrm{ac}} \\
0,984^{\mathrm{ab}} \\
0,382^{\mathrm{bc}}\end{array}$ \\
\hline $\begin{array}{l}\text { Laikas nuo trau- } \\
\text { mos iki pirmos } \\
\text { konsultacijos } \\
(\text { dienos)* }\end{array}$ & $31,0(19,8 ; 64,5)$ & $53,5(14,3 ; 229,3)$ & $28,0(11,5 ; 91,5)$ & $\begin{array}{l}0,431^{\mathrm{ac}} \\
0,695^{\mathrm{ab}} \\
0,414^{\mathrm{bc}}\end{array}$ \\
\hline $\begin{array}{l}\text { Laikas nuo pirmos } \\
\text { konsultacijos iki } \\
\text { antros (dienos)* }\end{array}$ & $24,5(11,5 ; 78,5)$ & $92,0(35,0 ; 138,8)$ & $23,0(9,0 ; 35,3)$ & $\begin{array}{c}1,000^{\mathrm{ac}} \\
0,001^{\mathrm{ab}} \\
<0,001^{\mathrm{bc}} \\
\end{array}$ \\
\hline $\begin{array}{l}\text { Laikas nuo trau- } \\
\text { mos iki operacijos } \\
(\text { dienos)* }\end{array}$ & $\begin{array}{c}166,0 \\
(97,0 ; 217,0)\end{array}$ & $\begin{array}{c}293,5 \\
(227,5 ; 354,0)\end{array}$ & $89,5(51,0 ; 180,25)$ & $\begin{array}{c}0,036^{\mathrm{ac}} \\
0,004^{\mathrm{ab}} \\
<0,001^{\mathrm{bc}} \\
\end{array}$ \\
\hline $\begin{array}{l}\text { Laikas nuo pirmos } \\
\text { konsultacijos iki } \\
\text { operacijos } \\
\text { (dienos)* }^{*}\end{array}$ & $75,5(47,0 ; 113,3)$ & $\begin{array}{c}208,5 \\
(165,0 ; 248,5)\end{array}$ & $43,0(20,8 ; 77,0)$ & $\begin{array}{l}0,006^{\mathrm{ac}} \\
<0,001^{\mathrm{ab}} \\
<0,001^{\mathrm{bc}}\end{array}$ \\
\hline
\end{tabular}

reikšmingumas nustatomas pasitelkiant Pearson chi kvadrato testą.

\section{Tyrimo rezultatai}

Iš viso nuo $2019 \mathrm{~m}$. liepos $16 \mathrm{~d}$. iki $2020 \mathrm{~m}$. lapkričio $9 \mathrm{~d}$. vieno ortopedo traumatologo buvo atliktos 2359 planinès konsultacijos ir 352 planinès operacijos. Nuo $2019 \mathrm{~m}$. liepos 16 d. iki $2020 \mathrm{~m}$. kovo 15d. ortopedas traumatologas atliko 1547 planines konsultacijas ir 225 planines operacijas, o per tą pati laikotarpi nuo $2020 \mathrm{~m}$. kovo $16 \mathrm{~d}$. iki $2020 \mathrm{~m}$. lapkričio $9 \mathrm{~d}$. beveik dvigubai mažiau: 812 planinių konsultacijų ir 127 planines operacijas (pirmojo karantino Lietuvoje metu neatlikta nei viena planiné operacija ar konsultacija). Darbo dienų operacinèje procentinè dalis nuo visu darbo dienų 1 grupejje statistiškai reikšmingai nesiskyrè nuo 2 grupès $(\mathrm{p}=0,504)$. Vidutinis operacijų skaičius per darbo dieną operacinèje 1 grupejje buvo $3,6 \pm 1,4$ ir statistiškai reikšmingai skyrèsi nuo vidutinio operacijų skaičiaus per darbo dieną 2 grupeje, kuris buvo $3,0 \pm 1,0$ operacijos per dieną $(\mathrm{p}=0,035)$. Darbo dienų konsultacinejje poliklinikoje procentinè dalis nuo visų darbo dienų statistiškai reikšmingai nesiskyre tarp 1 ir 2 grupių, o konsultacijų skaičiaus vidurkis per darbo dieną ir darbo valandą konsultacinèje poliklinikoje buvo statistiškai reikšmingai mažesnis 2 grupeje $(\mathrm{p}<0,001)$ (1 lentelè).

I tyrimą iš viso buvo ịtraukti 248 pacientai. Dauguma tiriamujų buvo moterys $(61,3 \%)$, amžiaus mediana (Q1;Q3) 57,0 (49,0; 63,0) metai. 94,8 proc. pacientų tai buvo pirmoji tos srities operacija. Dažniausiai atliktos buvo kelio operacijos be pilno priekinio kryžminio raiščio plyšimo $(33,1 \%)$ bei riešo tunelinio sindromo operacijos (23,0\%) (2 lentelè).

G2 grupès pacientų laukimo laiko nuo pirmos konsultacijos 
iki antros $\left(p=0,001^{\mathrm{ab}}\right.$, $\left.\mathrm{p}<0,001^{\text {bc }}\right)$, nuo traumos iki operacijos $\left(\mathrm{p}=0,004^{\mathrm{ab}}\right.$, $\mathrm{p}<0,001^{\mathrm{bc}}$ ) ir nuo pirmos konsultacijos iki operacijos $\left(\mathrm{p}<0,001^{\mathrm{ab}}, \mathrm{p}<0,001^{\mathrm{bc}}\right)$ medianos buvo statistiškai reikšmingai didesnès, lyginant su G1 ir G3 grupèmis. Lyginant G1 ir G3 grupes matome, jog G1 laukimo laiko mediana nuo traumos iki operacijos $\left(\mathrm{p}=0,036^{\mathrm{ac}}\right)$ ir nuo pirmos konsultacijos iki operacijos $\left(\mathrm{p}=0,006^{\mathrm{ac}}\right)$ buvo statistiškai reikšmingai didesnè, negu G3 (3 lentelè). Kitų statistiškai reikšmingų skirtumų tarp šiu grupių stebèta nebuvo.

G1 grupejje buvo mažesnè procentinè dalis kelio operacijų dèl visiško priekinio kryžminio raiščio plyšimo, lyginant su G3 grupe $\left(p=0,029^{a c}\right)$. Peties nesant visiško peties manžetės raumens plyšimo operacijų procentinè dalis nuo visų operacijų buvo statistiškai reikšmingai didesnè G2 grupèje, lyginant su G3 grupe $\left(\mathrm{p}=0,033^{\mathrm{bc}}\right)$. Kitų operacijos indikaciju ar trukmès statistiškai reikšmingu skirtumų tarp šiu grupių nebuvo (4 lentelè).

\section{Rezultatụ aptarimas}

Mūsu tyrime nustatyta, jog nuo pirmojo karantino Lietuvoje pradžios $(2020 \mathrm{~m}$. kovo $16 \mathrm{~d}$.) vienas gydytojas ortopedas traumatologas atliko beveik dvigubai mažiau planinių konsultacijų ir operacijų, lyginant su tokiu pat laikotarpiu iki karantino. Suteiktų planinių paslaugų kiekio mažèjimas aiškiai stebėtas ir kituose ankstyvuose tyrimuose visame pasaulyje, kurie apėmè ne tik ortopedines traumatologines paslaugas ir ne tik planines procedūras [6-11]. Pasaulio sveikatos organizacijos atliktame tyrime stebèta, jog iš dalies ar visiškai sutriko hipertenzijos, diabeto ir jo komplikacijų, vėžio gydymas atitinkamai 53, 49 ir 42 proc. tirtų šalių [7].

Mūsų gauti rezultatai rodo, kad pacientai prieš pirmaji karantiną Lietuvoje ilgiau laukè nuo traumos ir nuo pirmos planinès ortopedo traumatologo konsultacijos iki operacijos, lyginant su tais, kuriems pirmoji planinè ortopedo traumatologo konsultacija ir operacija atlikta po pirmojo karantino. Šiam rezultatui negalejo daryti įtakos tai, kokios operacijos buvo atliktos, koks buvo laukimo laikas nuo traumos iki pirmos planinès konsultacijos ir laikas nuo pirmos konsultacijos iki antros, kadangi šie rodikliai statistiškai reikšmingai nesiskyre tarp šių grupių. Laukimo laikas nuo traumos ir pirmos konsultacijos iki operacijos galèjo sutrumpetti dèl trumpesnio laukimo po antros konsultacijos. Šiuos rezultatus

4 lentelè. Atliktos planinès ortopedinès - traumatologinės operacijos ir jų trukmè.

*mediana (Q1;Q3); **vidurkis \pm standartinis nuokrypis; $n$-operaciju skaičius; PKR - priekinis kryžminis raištis; ${ }^{2 c}$ - lyginamos G1 ir G3 grupès; ${ }^{a b}$ - lyginamos G1 ir G2 grupes; ${ }^{b c}$-lyginamos G2 ir G3 grupès.

\begin{tabular}{|c|c|c|c|c|}
\hline \multirow[b]{2}{*}{ Kintamasis } & \multicolumn{3}{|c|}{ Tiriamųjų grupès } & \multirow[b]{2}{*}{ p reikšmė } \\
\hline & $\begin{array}{c}\text { G1 - pirmoji } \\
\text { konsultacija ir } \\
\text { operacija iki } \\
20200316^{\mathrm{a}} \\
(\mathrm{n}=143)\end{array}$ & $\begin{array}{c}\text { G2 - pirmoji } \\
\text { konsultacija iki } \\
20200316, \text { o } \\
\text { operacija po } \\
(n=44)\end{array}$ & $\begin{array}{c}\text { G3 - pirmoji } \\
\text { konsultacija ir } \\
\text { operacija po } \\
20200316^{c} \\
(n=61)\end{array}$ & \\
\hline $\begin{array}{l}\text { Kelio operacija nesant visiško } \\
\text { PKR plyšimo }\end{array}$ & $47,0(32,9 \%)$ & $17,0(38,6 \%)$ & $18,0(29,5 \%)$ & $\begin{array}{l}0,637^{\mathrm{ac}} \\
0,481^{\mathrm{ab}} \\
0,328^{\mathrm{bc}}\end{array}$ \\
\hline $\begin{array}{l}\text { Kelio operacija esant visiškam } \\
\text { PKR plyšimui }\end{array}$ & $1,0(0,7 \%)$ & $2,0(4,5 \%)$ & $4,0(6,6 \%)$ & $\begin{array}{l}0,029^{\mathrm{ac}} \\
0,138^{\mathrm{ab}} \\
0,661^{\mathrm{bc}}\end{array}$ \\
\hline $\begin{array}{l}\text { Peties operacija nesant visiško } \\
\text { peties manžetės raumens ply- } \\
\text { šimo }\end{array}$ & $20,0(14,0 \%)$ & $9,0(20,5 \%)$ & $4,0(6,6 \%)$ & $\begin{array}{l}0,132^{\mathrm{ac}} \\
0,300^{\mathrm{ab}} \\
0,033^{\mathrm{bc}}\end{array}$ \\
\hline $\begin{array}{l}\text { Peties operacija esant visiškam } \\
\text { peties manžetės raumens plyši- } \\
\text { mui }\end{array}$ & $23,0(16,1 \%)$ & $7,0(15,9 \%)$ & $11,0(18,0 \%)$ & $\begin{array}{l}0,732^{\mathrm{ac}} \\
0,978^{\mathrm{ab}} \\
0,776^{\mathrm{bc}}\end{array}$ \\
\hline $\begin{array}{l}\text { Riešo tunelinio sindromo ope- } \\
\text { racija }\end{array}$ & $33,0(23,1 \%)$ & $6,0(13,6 \%)$ & $18,0(29,5 \%)$ & $\begin{array}{l}0,331^{\mathrm{ac}} \\
0,178^{\mathrm{ab}} \\
0,056^{\mathrm{bc}}\end{array}$ \\
\hline $\begin{array}{l}\text { Riešo ir alkūnès tunelinio sin- } \\
\text { dromo operacija }\end{array}$ & $7,0(4,9 \%)$ & $0,0(0,0 \%)$ & $2,0(3,3 \%)$ & $\begin{array}{l}0,727^{\mathrm{ac}} \\
0,202^{\mathrm{ab}} \\
0,508^{\mathrm{bc}}\end{array}$ \\
\hline $\begin{array}{l}\text { Alkūnès tunelinio sindromo } \\
\text { operacija }\end{array}$ & $5,0(3,5 \%)$ & $0,0(0,0 \%)$ & $0,0(0,0 \%)$ & $\begin{array}{c}0,325^{\mathrm{ac}} \\
0,593^{\mathrm{ab}} \\
-{ }_{-}^{\mathrm{bc}}\end{array}$ \\
\hline Gangliono operacija & $1,0(0,7 \%)$ & $2,0(4,5 \%)$ & $1,0(1,6 \%)$ & $\begin{array}{l}0,510^{\mathrm{ac}} \\
0,138^{\mathrm{ab}} \\
0,570^{\mathrm{bc}}\end{array}$ \\
\hline Pèdos didžiojo piršto operacija & $5,0(3,5 \%)$ & $1,0(2,3 \%)$ & $3,0(4,9 \%)$ & $\begin{array}{l}0,698^{\mathrm{ac}} \\
0,687^{\mathrm{ab}} \\
0,638^{\mathrm{bc}}\end{array}$ \\
\hline Spragsinčio piršto operacija & $1,0(0,7 \%)$ & $0,0(0,0 \%)$ & $0,0(0,0 \%)$ & $\begin{array}{c}0,513^{\mathrm{ac}} \\
0,578^{\mathrm{ab}} \\
\quad-\mathrm{bc}\end{array}$ \\
\hline
\end{tabular}


būtų galima paaiškinti sumažejusiais pacientų srautais. Lyginant laikotarpi po planiniu ortopedinių traumatologinių paslaugų atnaujinimo (2020 m. birželio 15 d.) su laikotarpiu iki pirmojo karantino Lietuvoje, pastebèta, kad darbo dienų konsultacinejje poliklinikoje procentinè dalis nuo visų darbo dienų statistiškai reikšmingai nesiskyrè, o vidutinis konsultacijų skaičius per darbo dieną ir valandą buvo statistiškai reikšmingai mažesnis po karantino $(13,5 \pm 2,0 ; 2,4 \pm 1,0)$ nei iki jo $(17,6 \pm 1,6 ; 4,4 \pm 0,4)(p<0,001)$. Analogiškai stacionare: darbo dienų operacinejje procentinè dalis nuo visų darbo dienų statistiškai reikšmingai nesiskyrè laikotarpiais iki 2020 kovo 16 d. ir nuo 2020 birželio 15d., o vidutinis operacijų skaičius per darbo dieną operacinejje buvo statistiškai reikšmingai mažesnis po karantino $(3,0 \pm 1,0)$ nei iki jo $(3,6 \pm 1,4)(p=0,035)$. Tai rodo, kad buvo sumažèję pacientų srautai. Analogiška situacija stebèta ir kituose tyrimuose. JAV atliktas tyrimas rodo, jog kitomis ligomis (ne Covid-19) sergančių pacientų srautai buvo sumažèję 42,8 proc. ir 15,9 proc. atitinkamai balandị ir birželị (liepą), lyginant su laikotarpiu iki Covid-19 pandemijos. Nuo kitų ligų gydomų pacientų skaičius JAV taip pat normalizavosi, bet vis dar buvo mažesnis už ankstesnes apimtis [6]. Daug priežasčių galejo nulemti pacientų srautų sumažejimą, atnaujinus planines paslaugas. Mūsų tyrime darbo dienų konsultacinėje poliklinikoje ir operacinėje procentas nuo visų darbo dienų nesiskyrè iki karantino ir po planinių paslaugų atnaujinimo, paslaugos pacientams turèjo būti prieinamos. Galimų operacijų skaičių per darbo dieną ribojo sveikatos apsaugos ministro įsakymu nustatyti reikalavimai patalpų plotui, laiko tarpams tarp konsultacijų, konsultacijų kiekiui. Iš dalies ir pacientai bijojo kreiptis ị gydymo įstaigas, jei tai tikrai nebuvo būtina. Dẻl visuomenejje sklandančių mitų dalis pacientų bijojo atlikti Covid-19 PGR tyrimą, kurio metu imamas tepinèlis iš nosiaryklès ir ryklès, tad dèl šios priežasties atsisakè gydymo.

Mūsų tirti pacientai, kuriems pirmoji planinè ortopedo traumatologo konsultacija buvo atlikta iki pirmojo karantino Lietuvoje, o operacija po jo, ilgiau lauké nuo pirmos konsultacijos iki antros, nuo traumos iki operacijos ir nuo pirmos konsultacijos iki operacijos,

\begin{tabular}{|c|c|c|c|c|}
\hline $\begin{array}{l}\text { Kelio operacijos nesant visiško } \\
\text { PKR plyšimo trukmè (minutes)* }\end{array}$ & $\begin{array}{c}30,0 \\
(25,0 ; 40,0)\end{array}$ & $\begin{array}{c}30,0 \\
(22,5 ; 32,5)\end{array}$ & $\begin{array}{c}30,0 \\
(25,0 ; 45,0)\end{array}$ & $\begin{array}{l}0,831^{\text {ac }} \\
0,341^{\text {ab }} \\
0,521^{\text {bc }}\end{array}$ \\
\hline $\begin{array}{l}\text { Kelio operacijos esant visiškam } \\
\text { PKR plyšimui trukmė (minu- } \\
\text { tès)** }\end{array}$ & $90,0 \pm 0,0$ & $70,0 \pm 0,0$ & $71,3 \pm 13,8$ & $\begin{array}{l}0,310^{\text {ac }} \\
-a^{a b} \\
0,909^{\text {bc }}\end{array}$ \\
\hline $\begin{array}{l}\text { Peties operacijos nesant visiško } \\
\text { peties manžetès raumens ply- } \\
\text { šimo trukmė (minutės)* }\end{array}$ & $\begin{array}{c}47,5 \\
(40,0 ; 57,5)\end{array}$ & $\begin{array}{c}50,0 \\
(37,5 ; 65,0)\end{array}$ & $\begin{array}{c}50,0 \\
(32,5 ; 67,5)\end{array}$ & $\begin{array}{l}1,000^{\text {ac }} \\
0,675^{\text {ab }} \\
1,000^{\text {bc }}\end{array}$ \\
\hline $\begin{array}{l}\text { Peties operacijos esant visiškam } \\
\text { peties manžetės raumens plyši- } \\
\text { mui trukmė (minutės)** }\end{array}$ & $63,9 \pm 17,1$ & $67,1 \pm 12,2$ & $75,9 \pm 20,2$ & $\begin{array}{l}0,080^{\text {ac }} \\
0,646^{\text {ab }} \\
0,320^{\text {bc }}\end{array}$ \\
\hline $\begin{array}{l}\text { Riešo tunelinio sindromo opera- } \\
\text { cijos trukmè (minutès)* }\end{array}$ & $\begin{array}{c}20,0 \\
(20,0 ; 25,0)\end{array}$ & $\begin{array}{c}17,5 \\
(15,0 ; 22,5)\end{array}$ & $\begin{array}{c}20,0 \\
(20,0 ; 21,3)\end{array}$ & $\begin{array}{l}0,298^{\text {ac }} \\
0,638^{\text {ab }} \\
1,000^{\text {bc }}\end{array}$ \\
\hline $\begin{array}{l}\text { Riešo ir alkūnės tunelinio sin- } \\
\text { dromo operacijos trukmė (mi- } \\
\text { nutès)* }\end{array}$ & $\begin{array}{c}20,0 \\
(20,0 ; 25,0)\end{array}$ & - & $30,0(25,0 ;-)$ & $\begin{array}{l}0,417 \text { ac } \\
- \text { ab } \\
-b c \\
\end{array}$ \\
\hline $\begin{array}{l}\text { Gangliono operacijos trukmé } \\
\text { (minutess)** }\end{array}$ & $40,0 \pm 0,0$ & $32,5 \pm 3,5$ & $30,0 \pm 0,0$ & $\begin{array}{l}-{ }^{-a c} \\
0,333^{\text {ab }} \\
0,667^{\text {bc }}\end{array}$ \\
\hline $\begin{array}{l}\text { Pėdos didžiojo piršto operacijos } \\
\text { trukmè (minutès)* }\end{array}$ & $\begin{array}{c}65,0 \\
(57,5 ; 105,0)\end{array}$ & - & $55,0(55,0 ;-)$ & $\begin{array}{l}1,000^{\text {ac }} \\
- \text { ab } \\
-b c\end{array}$ \\
\hline
\end{tabular}

lyginant su pacientais operuotais prieš pirmaji karantiną ir su tais, kuriems pirmoji planinè konsultacija ir operacija atlikta po karantino. Tai nebuvo netikèta, kadangi Lietuvoje, kaip ir kitose šalyse, $2020 \mathrm{~m}$. pavasarị buvo sustabdytas planiniu paslaugų teikimas, siekiant perskirstyti turimus išteklius Covid-19 gydymui [12-14].

Šio tyrimo yra keletas apribojimų. Tyrimas retrospektyvus, todèl teko atmesti kai kuriuos pacientus dèl reikalingų duomenų trūkumo. Tyrème tik tuos pacientus, kuriems jau buvo atliktos planinès ortopedinès traumatologinès paslaugos ir nevertinome, koks kiekis pacientų jų dar tik laukia. Tirti vieno gydytojo ortopedo traumatologo viename centre konsultuoti ir operuoti pacientai, tad yra apribojimų siekiant pritaikyti šio tyrimo rezultatus visai Lietuvos populiacijai.

\section{Išvados}

1. Ortopedo traumatologo planinių konsultacijų ir operacijų skaičius nuo pirmojo (2020 m. kovo 16 d.) iki antrojo karantino Lietuvoje paskelbimo pradžios (2020 m. lapkričio 9 d.) buvo beveik dvigubai mažesnis, lyginant su tuo pačiu laikotarpiu prieš karantiną.

2. Atnaujinus planines ortopedines traumatologines paslaugas po pirmojo karantino Lietuvoje, pacientų srautas buvo mažesnis negu iki karantino, todèl 
sutrumpejo laukimo laikas nuo traumos ir pirmos planinès ortopedo traumatologo konsultacijos iki operacijos.

3. Labiausiai pandemija paveikè pacientus, kurie pirmają planinę ortopedo traumatologo konsultaciją gavo iki karantino, o buvo operuojami po karantino. Šie pacientai ilgiau laukè nuo pirmos konsultacijos iki antros, nuo traumos ir pirmos konsultacijos iki operacijos, lyginant su tais, kurie buvo operuoti iki karantino ar gavo pirmają planinę ortopedo traumatologo konsultaciją ir buvo operuoti po karantino.

\section{Literatūra}

1. Yesudhas D, Srivastava A, Gromiha MM. COVID-19 outbreak: history, mechanism, transmission, structural studies and therapeutics. Infection, Springer 2020;1:3. https://doi.org/10.1007/s15010-020-01516-2

2. Liu YC, Kuo RL, Shih SR. COVID-19: the first documented coronavirus pandemic in history. Biomedical Journal, Elsevier BV 2020;43:328-333. https://doi.org/10.1016/j.bj.2020.04.007

3. Dos Santos WG. Natural history of COVID-19 and current knowledge on treatment therapeutic options. Biomedicine and Pharmacotherapy, Elsevier Masson SAS 2020;129:110493. https://doi.org/10.1016/j.biopha.2020.110493

4. Speth MM, Singer-Cornelius T, Oberle M, Gengler I, Brockmeier SJ, Sedaghat AR. Olfactory dysfunction and sinonasal symptomatology in COVID-19: prevalence, severity, timing, and associated characteristics. Otolaryngology - Head Neck Surgery (United States) 2020;163(1):114-120. https://doi.org/10.1177/0194599820929185

5. Coronavirus. World health organisation. https://www.who.int/ health-topics/coronavirus\#tab=tab_3

6. Birkmeyer JD, Barnato A, Birkmeyer N, Bessler R, Skinner J. The impact of the COVID-19 pandemic on hospital admissions in the United States. Health Affairs 2020;39(11):2010-2017. https://doi.org/10.1377/hlthaff.2020.00980

7. Brunier A, Harris M. COVID-19 significantly impacts health services for noncommunicable diseases. World health organisation. https:/www.who.int/news/item/01-06-2020-covid19-significantly-impacts-health-services-for-noncommunicable-diseases

8. Thirunarayanan IV. Impact of COVID-19 pandemic on orthopedic practice-results of a survey. Clin Clin Pr 2020;17(4):15161521.

9. Ruggieri P, Trovarelli G, Angelini A, Pala E, Berizzi A, Donato D. COVID-19 strategy in organizing and planning orthopedic surgery in a major orthopedic referral center in an area of Italy severely affected by the pandemic: Experience of the Department of Orthopedics, University of Padova. J Orthop Surg Res 2020;15(1):279. https://doi.org/10.1186/s13018-020-01740-4

10. Hernigou J, Valcarenghi J, Safar A, Ferchichi MA, Chahidi E,
Jennart H, et al. Post-COVID-19 return to elective orthopaedic surgery - is rescheduling just a reboot process? Which timing for tests? Is chest CT scan still useful? Safety of the first hundred elective cases? How to explain the "new normality health organization" to patients? Int Orthop 2020;44(10):1905-1913. https://doi.org/10.1007/s00264-020-04728-1

11. Randau TM, Jaenisch M, Haffer H, Schömig F, Kasapovic A, Olejniczak K, et al. Collateral effect of COVID-19 on orthopedic and trauma surgery. PLoS One 2020;15(9):e0238759. https://doi.org/10.1371/journal.pone.0238759

12. Surgeons say COVID waiting list time bomb has 'already detonated'. Royal College of Surgeons of England 2020. https:// www.rcseng.ac.uk/news-and-events/media-centre/press-releases/waiting-list-time-bomb/

13. Griffin S. Covid-19: waiting times in England reach record highs. BMJ 2020;370:m3557.

https://doi.org/10.1136/bmj.m3557

14. Aubusson K. COVID-19 a plague on elective surgery wait lists. The Sydney Morning Herald 2020.

\section{THE CHANGES IN THE AVAILABILITY OF ELECTIVE ORTHOPEDIC TRAUMATOLOGIC SERVICES DURING COVID-19 PANDEMIC}

A. Česnauskaitè, A. Montrimas, V. Venclovas

Keywords: Covid-19 pandemic, elective orthopaedic traumatologic services.

Summary

Background. On 11 $1^{\text {th }}$ of March 2020 the World Health Organisation announced Covid-19 pandemic and many healthcare providers had to allocate resources for treatment of Covid-19 patients from other healthcare sectors. The aim of this study was to evaluate the changes in the availability of elective orthopaedic traumatologic services during Covid-19 pandemic.

Methods. This is a retrospective study. The population of the study was patients who had elective consultations and operations by one orthopaedic traumatologist in LUHS Kauno ligonine Surgery clinic (Hipodromo g. 13) from $16^{\text {th }}$ of July 2019 until $9^{\text {th }}$ of November 2020. All the patients were divided into 3 groups: G1 patients operated until the $1^{\text {st }}$ quarantine in Lithuania $\left(16^{\text {th }}\right.$ of March 2020) (143 patients); G2 - patients who had their $1^{\text {st }}$ elective orthopaedic traumatologic consultation before $16^{\text {th }}$ of March 2020 and the operation after (44 patients); G3 - subjects who had their $1^{\text {st }}$ elective orthopaedic traumatologic consultation and operation after $16^{\text {th }}$ of March 2020 (61 patient). These groups were compared and the statistical analysis was performed using IBM SPSS Statistics software (v.26.0).

Results. One orthopaedic traumatologist had 1547 elective consultations as well as 225 elective operations from $16^{\text {th }}$ of July 2019 until the $15^{\text {th }}$ of March 2020 and 812 elective consultations as well as 127 elective operations from $16^{\text {th }}$ of March 2020 until the $9^{\text {th }}$ of November 2020. Before the $1^{\text {st }}$ quarantine in Lithuania the average number of elective operations (3.6 \pm 1.4$)$ and consultations $(17.6 \pm 1.6)$ per work day in operating theatre and ambulatory clinic was statistically significantly larger than after the 
$1^{\text {st }}$ quarantine: $3.0 \pm 1.0(\mathrm{p}=0.035)$ and $13.5 \pm 2.0(\mathrm{p}<0.001)$ accordingly. The medians of waiting time from the $1^{\text {st }}$ consultation until the $2^{\text {nd }}\left(p=0.001^{\mathrm{ab}}, \mathrm{p}<0.001^{\mathrm{bc}}\right)$, from trauma until the operation $\left(p=0.004^{\text {ab }}, p<0.001^{\mathrm{bc}}\right)$ and from the $1^{\text {st }}$ consultation until the operation ( $p<0.001^{\mathrm{ab}}, \mathrm{p}<0.001^{\mathrm{bc}}$ ) were statistically significantly larger in G2 group when compared to G1 and G3. The medians of waiting time from trauma until the operation $\left(\mathrm{p}=0,036^{\mathrm{ac}}\right)$ and from the $1^{\text {st }}$ consultation until the operation $\left(\mathrm{p}=0,006^{\text {ac }}\right)$ were statistically significantly larger in G1 group when compared to G3.

Conclusions. The number of one orthopaedic traumatologist's elective consultations and operations was almost twice as low during the period from the $1^{\text {st }}$ quarantine in Lithuania $\left(16^{\text {th }}\right.$ of March 2020 ) until the beginning of the $2^{\text {nd }}$ quarantine ( $9^{\text {th }}$ of November 2020) when compared to the same period of time before the quarantines. The number of elective orthopaedic traumatologic services remained lower as they were resumed after the $1^{\text {st }}$ quarantine in Lithuania but the waiting time from trauma and the $1^{\text {st }}$ consultation until the operation became shorter. Patients who had their $1^{\text {st }}$ elective orthopaedic traumatologic consultation before the $1^{\text {st }}$ quarantine in Lithuania and the operation after had to wait longer from the $1^{\text {st }}$ consultation to the $2^{\text {nd }}$, from trauma to the $1^{\text {st }}$ consultation and from the $1^{\text {st }}$ consultation to the operation when compared to those who had their operation before the $1^{\text {st }}$ quarantine or had their $1^{\text {st }}$ consultation and operation after the $1^{\text {st }}$ quarantine in Lithuania.

Correspondence to: venclovasvytautas@gmail.com

Gauta 2021-03-15 